\title{
Acoustic observations of jellyfish in the Namibian Benguela
}

\author{
Andrew S. Brierley ${ }^{1, *}$, Bjørn Erik Axelsen ${ }^{2}$, Emmanuelle Buecher ${ }^{3,4}$, \\ Conrad A. J. Sparks ${ }^{5}$, Helen Boyer ${ }^{6}$, Mark J. Gibbons ${ }^{3}$ \\ ${ }^{1}$ Biological Sciences Division, British Antarctic Survey, High Cross, Madingley Road, Cambridge CB3 0ET, United Kingdom \\ ${ }^{2}$ Institute of Marine Research, PO Box 1870 Nordnes, 5817 Bergen, Norway \\ ${ }^{3}$ Zoology Department, University of the Western Cape, Private Bag X17, Bellville 7535, South Africa \\ ${ }^{4}$ Laboratoire d'Océanographie Biologique et Ecologie du Plancton Marin, CNRS/UPMC 7076 Station Zoologique, BP 28, \\ 06234 Villefranche-sur-Mer, France \\ ${ }^{5}$ Department of Nature Conservation and Oceanography, School of Life Science, Cape Technikon, PO Box 652, Cape Town, \\ South Africa \\ ${ }^{6}$ National Information and Marine Research Center, PO Box 912, Swakopmund, Namibia
}

\begin{abstract}
Multi-frequency acoustic data (18, 38 and $120 \mathrm{kHz})$ were collected in conjunction with pelagic trawl sampling for gelatinous macrozooplankton during a cruise to the Namibian Benguela in September 1999. Sampling focused specifically on the scyphozoan Chrysaora hysoscella and the hydrozoan Aequorea aequorea, both of which occur in large numbers, are probably of major ecological importance, and physically hamper pelagic fishing and diamond extraction activities. C. hysoscella was detected predominantly at an inshore station and $A$. aequorea was found in greatest abundance further offshore in deeper water. Echo-sounder observations were linked directly to net catches, and relationships between catch density (number of individuals $\mathrm{m}^{-3}$ ) and nautical area scattering coefficients $\left(s_{\mathrm{A}}\right)$ at each frequency were determined for both species in order to estimate target strength (TS) using the comparison method. TS for C. hysoscella (mean umbrella diameter $26.8 \mathrm{~cm}$ ) was $-51.5 \mathrm{~dB}$ at $18 \mathrm{kHz},-46.6 \mathrm{~dB}$ at $38 \mathrm{kHz}$ and $-50.1 \mathrm{~dB}$ at $120 \mathrm{kHz}$; for $A$. aequorea (mean central umbrella diameter $7.4 \mathrm{~cm}$ ) TS was $-68.1 \mathrm{~dB}$ at $18 \mathrm{kHz},-66.3 \mathrm{~dB}$ at $38 \mathrm{kHz}$ and $-68.5 \mathrm{~dB}$ at $120 \mathrm{kHz}$. These TS values compared favourably with previously published estimates for related species. Jellyfish were caught at high numerical densities (maxima 3 C. hysoscella per $100 \mathrm{~m}^{3}, 168$ A. aequorea per $100 \mathrm{~m}^{3}$ ). These high densities, combined with the not unsubstantial TS at frequencies used for fisheries surveys, imply that jellyfish could potentially bias acoustic estimates of fish abundance. We suggest a simple multifrequency approach that could be used to discriminate between echoes from jellyfish and some commercially important pelagic fish in the northern Benguela ecosystem.
\end{abstract}

KEY WORDS: Acoustics · Chrysaora hysoscella · Aequorea aequorea $\cdot$ Multi-frequency · Target strength $\cdot$ Benguela $\cdot$ Jellyfish $\cdot$ Namibia

Resale or republication not permitted without written consent of the publisher

\section{INTRODUCTION}

The jellyfish Chrysaora hysoscella (class Scyphozoa) and Aequorea aequorea (class Hydrozoa) are abundant in Namibian waters. There is some evidence to

*E-mail: a.brierley@bas.ac.uk suggest that prior to the 1970s this was not the case (e.g. Hart \& Currie 1960, Stander \& de Decker 1969), and it is possible therefore that these species have become established as a major component of the northern Benguela ecosystem over the course of just 2 or 3 decades (Fearon et al. 1991). Rapid increases in abundance (blooms) of gelatinous carnivores (including medusae, siphonophores and ctenophores) have 
been reported in recent years from numerous marine ecosystems worldwide (e.g. Mills 1995). The increase in jellyfish abundance in the northern Benguela appears to have coincided with a period of declining pelagic fish catches there (Shannon et al. 1992, FAO 1995), and it has been suggested that these phenomena are directly linked. Although the diets of C. hysoscella and A. aequorea are not well described, related species are known to prey upon fish eggs and larvae (e.g. Purcell et al. 1987, 1994, Purcell 1989); jellyfish also consume other zooplankton that are themselves important sources of food for fish (e.g. Purcell 1992, Suchman \& Sullivan 1998). Introduction of the ctenophore Mnemiopsis leidyi to the Black Sea has been implicated in the crash of fish stocks there (Travis 1993), and the pattern of increasing jellyfish abundance following finfish decline is becoming well established (Purcell et al. 1999). In addition to their potential predatory and competitive impacts on fish abundance, jellyfish hamper fishing activities off Namibia physically by clogging and subsequently bursting trawl nets. Jellyfish also cause localised problems to the inshore diamond mining industry because they can block the suction devices used to mine marine alluvial sediments.

Despite the probable ecological importance of jellyfish in the northern Benguela ecosystem, and the economic consequences that their large numbers bring, little is known of the biology or population dynamics of Chrysaora hysoscella or Aequorea aequorea, or indeed of gelatinous zooplankton there generally (Gibbons et al. 1992). Some information on the distribution and abundance of $C$. hysoscella and A. aequorea is available from Bongo net surveys (Fearon et al. 1991, Pagès 1991), but these nets were small $(57 \mathrm{~cm}$ mouth opening) and are unlikely to have provided unbiased data, particularly for adult $C$. hysoscella that attain umbrella diameters exceeding $50 \mathrm{~cm}$. A knowledge of patterns of species distribution and abundance are amongst the most basic requirements for understanding population biology processes, and will be vital for developing hypotheses to explain the behaviour of $C$. hysoscella and $A$. aequorea populations off Namibia.

Acoustic techniques are used commonly for studies of distribution and abundance of fish (e.g. MacLennan \& Simmonds 1992) and zooplankton (e.g. Brierley et al. 1997), enabling large areas of ocean to be surveyed non-invasively in relatively short periods of time. Acoustic measurements of caged specimens of the common jellyfish Aurelia aurita (Mutlu 1996) and laboratory-held gelatinous zooplankters Aequorea victoria and Pleurobrachia bachei (Monger et al. 1998) have shown that jellyfish can be detected acoustically, and fishery-acoustic survey techniques may therefore be applicable for these animals too. Jellyfish have also been detected acoustically near the sea floor during seismic surveys (L. Ricketts, de Beers Marine, pers. comm. 2000). To our knowledge though, there are very few published studies on the use of acoustics at sea to study jellyfish (but see Toyokawa et al. 1997 and references therein, and Purcell et al. 2000), and those studies that are available are predominantly qualitative. The high abundances of Aequorea aequorea and Chrysaora hysoscella along the Namibian coast provide excellent opportunities for studying jellyfish at sea, as well as a strong motivation for describing their acoustic characteristics: knowledge of mesoscale distribution and abundance variation, which acoustic surveys may be able to provide, would be of great value to a number of parties operating in Namibian waters.

The study reported here was instigated with the general aim of assessing the applicability of acoustic survey techniques at sea for quantitative studies of jellyfish. Specifically our objectives were: (1) to determine the target strengths (TS) of Chrysaora hysoscella and Aequorea aequorea at frequencies used on fisheries surveys - TS is required to convert echo intensity to animal numerical density; (2) to obtain multifrequency acoustic data from single-species aggregations of $C$. hysoscella and A. aequorea that may enable these species to be both identified (in a similar manner to techniques that have previously been developed for crustacean zooplankton [Brierley et al. 1998] and fish [Simmonds et al. 1996]) and distinguished acoustically from commercially important fish; and (3) to describe the off/inshore distribution of these jellyfish species.

\section{MATERIALS AND METHODS}

Survey details. The jellyfish survey was conducted from the FRV 'Dr Fridtjof Nansen' between August 31 and September 6, 1999. The cruise was a component of the Benguela Environment Fisheries Interaction and Training (Benefit) Programme, which is a regional partnership between Namibia, Angola and South Africa focused on fisheries and marine resources of the Benguela Current ecosystem off southwest Africa (see www.benefit.org.na).

The ship sailed from Walvis Bay and, after initial netting trials, occupied an inshore station for a $24 \mathrm{~h}$ period between September 2 and 3. This station, at $21^{\circ} 27^{\prime} \mathrm{S}$, $13^{\circ} 38^{\prime} \mathrm{E}$, had a water depth of $85 \mathrm{~m}$. An offshore station, at $21^{\circ} 59^{\prime} \mathrm{S}, 13^{\circ} 08^{\prime} \mathrm{E}$, was occupied for a similar period between September 4 and 5. Water depth there was $225 \mathrm{~m}$. Finally an off/inshore transect was run during daylight on September 5 along $22^{\circ} \mathrm{S}$ between $12^{\circ} 42^{\prime} \mathrm{E}$ (water depth $430 \mathrm{~m}$ ) and $13^{\circ} 47^{\prime} \mathrm{E}$ (102 m). Net samples were taken along this transect at intervals corresponding to approximately $50 \mathrm{~m}$ reductions in bottom depth. Station positions are shown in Fig. 1. 


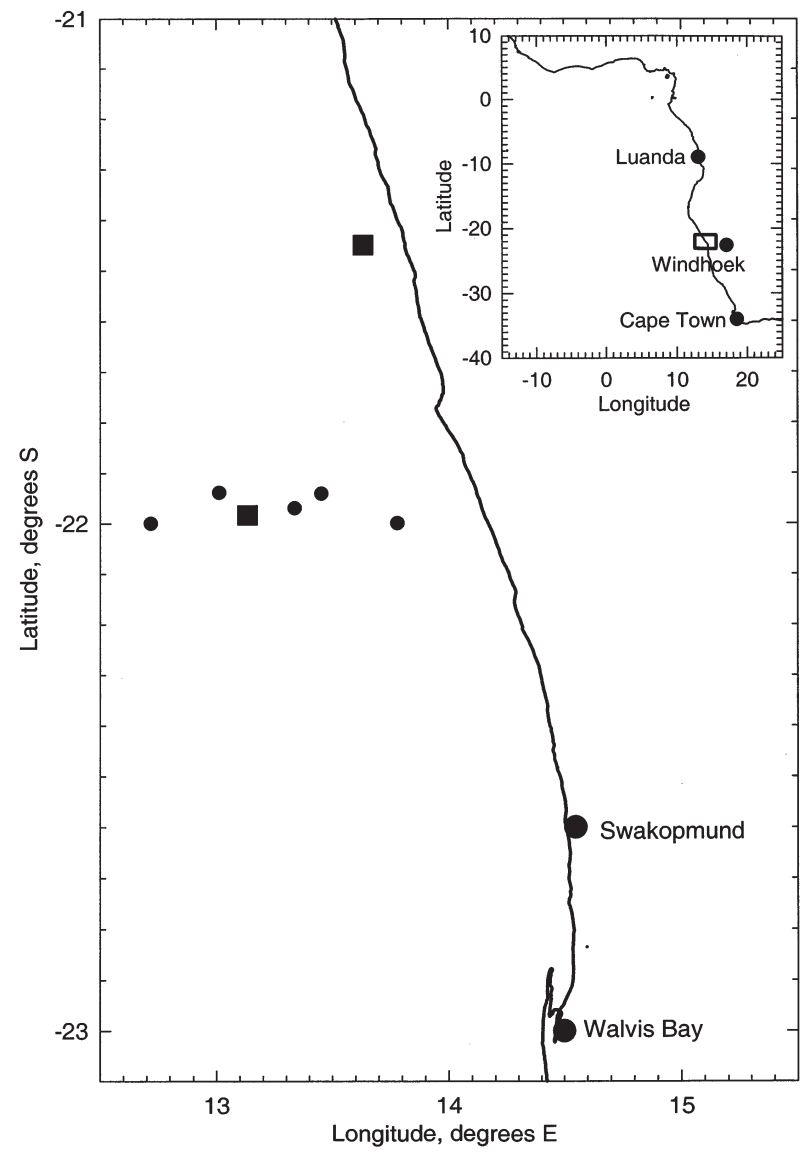

Fig. 1. Map showing $24 \mathrm{~h}$ sampling stations (匹) and CTD/ trawling stations along the transect at $22^{\circ} \mathrm{S}(\bullet)$ off the Namibian coast

Acoustic sampling. A Simrad EK500 echo-sounder operating 18,38 and $120 \mathrm{kHz}$ split-beam transducers was run continuously throughout the cruise. The 38 and $120 \mathrm{kHz}$ transducers were mounted on a drop keel at a depth of $8 \mathrm{~m}$, and the $18 \mathrm{kHz}$ transducer was mounted on the ship's hull at $5.5 \mathrm{~m}$. All 3 echo-sounder frequencies were calibrated using standard target spheres on September 12, 1999, at Sandy Point, South Africa. Echo-sounder settings and calibration parameters are given in Table 1.
Acoustic data were logged ping-by-ping over an ethernet to PC using SonarData Echolog_EK software. Ping repetition rate varied with water depth, but was of the order of 1 ping s ${ }^{-1}$.

Trawl sampling. Net samples were taken with 4panel pelagic trawls equipped with Scanmar acoustic transponders that provided information on head-rope depth. Two nets were used which, although of different overall sizes, were of the same design (modified Åkrehamn trawl, Valdemarsen \& Misund 1994) and were identical from the belly-opening backwards, both having $12 \mathrm{~m}$ diameter circular mouth openings (mesh size reducing from 400 to $36 \mathrm{~mm}$ ): for jellyfish, which will not exhibit a herding response to the net extensions (mesh sizes from 1.6 to $3.2 \mathrm{~m}$ ), we believe that both nets had the same effective fishing size and efficiency. The smaller net was fitted with a multisampler (Skeide et al. 1997) and 3 cod ends that enabled 3 separate samples to be obtained from a single trawl deployment. The trawl warp for the large net was equipped with balloon floats that kept the net nearsurface (effective fishing depth between 19 and $31 \mathrm{~m}$ ). The smaller net was fished throughout the water column and was most often used to collect samples at 3 discrete depths per deployment. Net hauls were typically conducted at 3 knots and were of 5 min duration (extending approximately $450 \mathrm{~m}$ horizontally), except on occasions when very dense concentrations of jellyfish were evident in surface waters and deployments were cut short.

Hydrographic sampling. Casts were made to nearbottom with a Seabird SBE911+ CTD at both of the $24 \mathrm{~h}$ sampling stations and at each of the sampling sites on the off/inshore transect along $22^{\circ} \mathrm{S}$. Temperature and salinity data were de-spiked and used to derive density (sigma 0). Oxygen concentration was also recorded, although these data can only be considered in relative terms since the water samples needed to calibrate the sensor were not taken.

Catch analysis. Net samples were analysed immediately after the net was recovered to determine total number and wet mass of Chrysaora hysoscella, Aequorea aequorea and all other fish and cephalopod

Table 1. Echo-sounder settings. TS: target strength; SV: volume backscattering strength; Cu: copper; WC: tungsten carbide

\begin{tabular}{|lccc|}
\hline & & \multirow{2}{*}{ Frequency (kHz) } & 38 \\
\cline { 2 - 4 } & 18 & ES38B & 120 \\
\hline Transducer type & ES18-11 & 1 (medium) & ES120-7 \\
Pulse duration (ms) (Simrad descriptor) & 0.7 (short) & 3.8 (wide) & 1 (long) \\
Bandwidth (kHz) (Simrad descriptor) & 1.8 (wide) & $60 \mathrm{~mm} \mathrm{Cu}$ & 1.2 (narrow) \\
Calibration sphere & $60 \mathrm{~mm} \mathrm{Cu}$ & $27.65(27.65)$ & $38.1 \mathrm{~mm}$ WC \\
Calibrated TS gain (dB) (value used on survey) & $21.60(21.50)$ & $27.45(27.45)$ & $26.17(25.62)$ \\
Calibrated SV gain (dB) (value used on survey) & $21.69(21.70)$ & $26.01(25.62)$ \\
\hline
\end{tabular}


species. Catches were often very large (several tonnes), and on these occasions random subsamples were taken in $40 \mathrm{l}$ fish baskets. Total catch was estimated by multiplying mass and number values per basket by the total number of baskets caught. Jellyfish numerical density was estimated by dividing the total number of each species in the catch by the volume of water sampled $(=36 \pi \times$ horizontal extent of trawl; trawl extent calculated from positions of net shooting and hauling as recorded in the ship's log). Umbrella diameter and wet mass for all jellyfish, or a random sample of $50 \mathrm{in}$ dividuals of each species, whichever was the lesser, were measured. C. hysoscella diameter was measured to the nearest $\mathrm{cm}$, and $A$. aequorea to the nearest 0.5

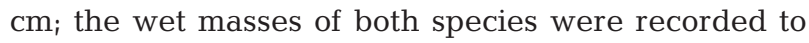
the nearest $0.01 \mathrm{~kg}$. Measures of wet mass and total animal volume were made for individual specimens of both jellyfish species so that their body tissue densities could be determined.

Acoustic analysis. Acoustic data (pings) were timestamped on collection. Those data corresponding to each trawl sample were identified using net-depth, wire-out and simple trigonometry to replot net trajectories over echograms. For example, when fishing the large net near-surface, $130 \mathrm{~m}$ of wire were typically payed out which, at a towing speed of 3 knots, equated to a time offset of $84 \mathrm{~s}$ between the acoustic and net samples: on a haul to $150 \mathrm{~m}$ depth, $450 \mathrm{~m}$ of wire were required and this resulted in a $292 \mathrm{~s}$ offset between echo-sounder and net.

Acoustic data corresponding to the section of the water column sampled by the net (typically $12 \mathrm{~m}$ deep by $450 \mathrm{~m}$ horizontally) were integrated using SonarData Echoview software to determine the nautical area scattering coefficients, $s_{\mathrm{A}}$ (units $=\mathrm{m}^{2}$ nautical mile ${ }^{-2}$, terminology after MacLennan \& Fernandes 1999), for each of the 3 frequencies. The subsequent analysis then involved 4 stages: First, for net samples where Chrysaora hysoscella contributed $>95 \%$ by wet mass to the total catch, and where no fish were caught, $s_{\mathrm{A}}$ was plotted against the $C$. hysoscella numerical density (individuals $\mathrm{m}^{-3}$ ) determined from the net sample in order to investigate relationships between jellyfish numerical density and echo intensity. Linear regression analysis was used to describe and test the significance of these relationships. This approach of linking echo intensity to a net or other independent estimate of species density has been used widely (e.g. Misund \& Beltestad 1996, Gal et al. 1999) and is often referred to as the comparison method (MacLennan \& Simmonds 1992). Second, $s_{\mathrm{A}}$ values for trawls where Aequorea aequorea contributed $>80 \%$ by wet mass to the total catch (catches of pure A. aequorea were rare), and where the remainder of the catch was predominantly C. hysoscella and no fish were caught, were corrected for $C$. hysoscella numerical density using the regression equations from Stage 1. Corrected $s_{\mathrm{A}}$ values were then plotted against $A$. aequorea numerical density to obtain density/echo intensity relationships for this species. Third, TS for an individual was calculated for both species at each of the 3 frequencies as follows: mean acoustic backscattering cross section $<\sigma_{\mathrm{bs}}>\left(\mathrm{m}^{2}\right)$ was determined using the equation

$$
\rho_{\mathrm{v}}=\frac{s_{\mathrm{A}}}{1852^{2}<\sigma_{\mathrm{bs}}>\Delta z} \quad(1 ; \text { see Ona 1999) }
$$

where $\rho_{\mathrm{v}}$ (volume density, individuals $\mathrm{m}^{-3}$ ) and $s_{\mathrm{A}}$ are means as determined from the species- and frequencyspecific regression equations, and $\Delta z$ is the depth over which the acoustic data were integrated $(12 \mathrm{~m}$ in this case, the effective opening of the net). $<\sigma_{b s}>$ was then expressed as TS in decibels $(\mathrm{dB})$ from

$$
\mathrm{TS}=10 \log _{10} \frac{<\sigma_{\mathrm{bs}}>}{4 \pi}
$$

Finally, for each species, TS values determined as above for appropriate individual trawls were plotted against $\log _{10}$ mean umbrella diameter for jellyfish in those trawls to investigate TS/size relationships.

\section{RESULTS}

A total of 66 net hauls were made during the $5 \mathrm{~d}$ survey. Of these, 8 burst under the strain of excessive catches of jellyfish and had to be excluded from analyses because they could not be considered to be quantitative. An additional 2 hauls had to be discarded because either the trawl warp broke or the multisampler acoustic release failed. 14 trawl samples were dominated by Aequorea aequorea ( $>80 \%$ wet mass) and 11 contained $>95 \%$ wet mass Chrysaora hysoscella. The remaining hauls could not be used for the purpose of comparison with acoustic data because the catch was either too close to a 1:1 mix of A. aequorea/ C. hysoscella to allow backscatter to be attributed solely to one or other species, or was contaminated with fish (including hake, horse mackerel and myctophids) or cephalopods.

From those net samples that were subsequently used for comparison with acoustic data, the mean umbrella diameters of Chrysaora hysoscella and Aequorea aequorea were 26.8 and $7.4 \mathrm{~cm}$ respectively. For $A$. aequorea this diameter refers to the thick central disk of the umbrella. Size-frequency distributions for both species are shown in Fig. 2. A. aequorea has a very fragile umbrella margin which was missing or damaged in the majority of individuals we recovered from the net. Eight intact jellyfish were obtained during this study, from which we have estimated that the central 

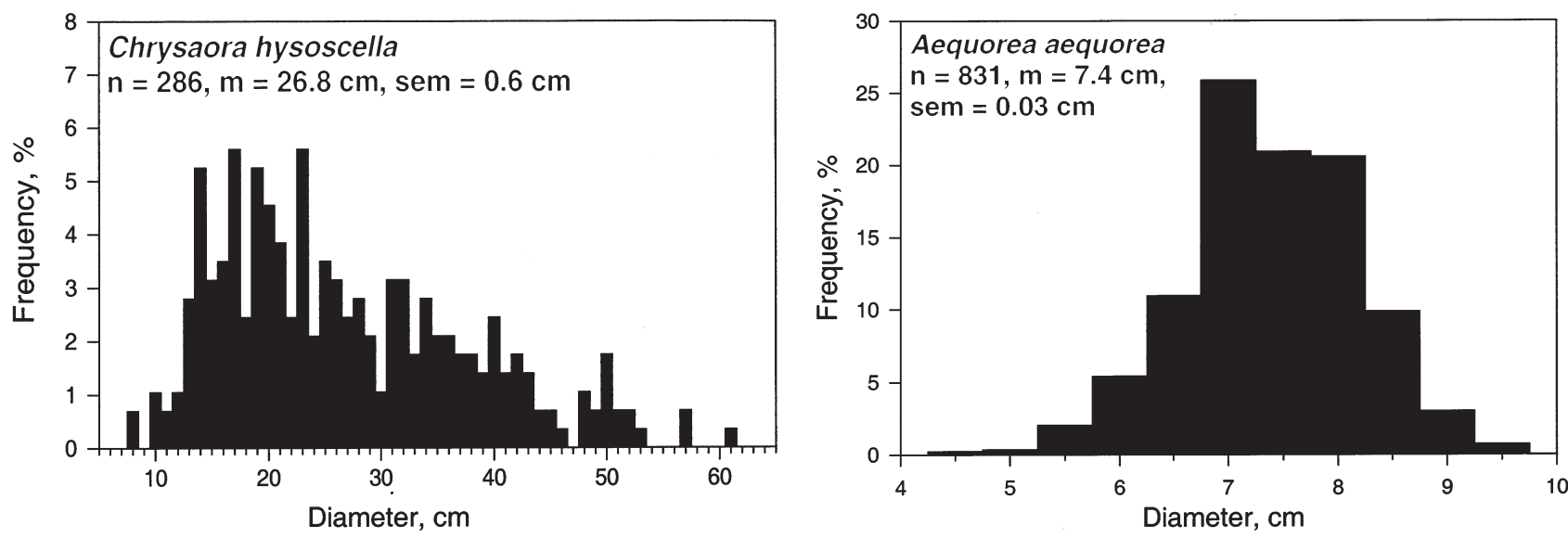

Fig. 2. Chrysaora hysoscella and Aequorea aequorea. Umbrella diameter frequency distributions for jellyfish from net samples used for comparison with acoustic data $(\mathrm{n}=$ sample size, $\mathrm{m}=$ mean, sem = standard error of the mean). Diameters for A. aequorea are for the central umbrella disk

disk contributes $56 \%( \pm 9 \%)$ to total diameter and $44 \%$ $( \pm 12 \%)$ to total wet mass. Mean wet mass was $1.15 \mathrm{~kg}$ for C. hysoscella and $0.06 \mathrm{~kg}$ for A. aequorea. Animal tissue density was $0.996 \mathrm{~kg} \mathrm{l}^{-1}$ for C. hysoscella and $1.014 \mathrm{~kg} \mathrm{l}^{-1}$ for $A$. aequorea, although it is not possible for us to conclude whether these values differ significantly.

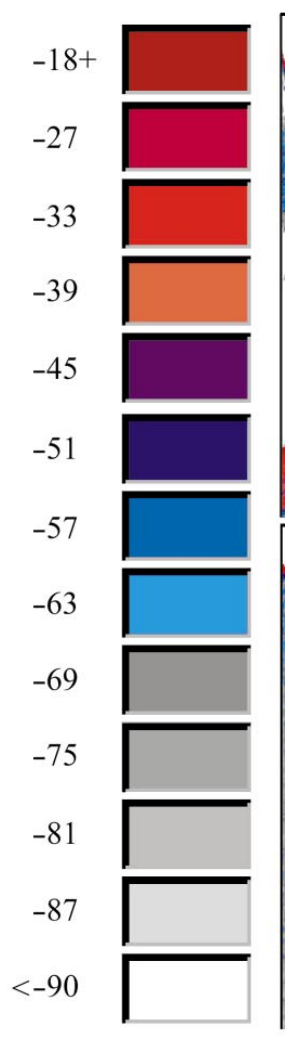

In broad terms, Chrysaora hysoscella was most common at the inshore station, whereas Aequorea aequorea was found in greater concentrations further offshore (see Sparks et al. 2000 for more details). The inshore site was dominated by the presence of a persistent scattering layer of about $25 \mathrm{~m}$ vertical extent (Figs. $3 \& 4 \mathrm{~A}$ ). The layer undulated, but was never

Fig. 3. Chrysaora hysoscella (upper panels) and Aequorea aequorea (lower panels). Typical daytime $38 \mathrm{kHz}$ (left panels) and $120 \mathrm{kHz}$ (right panels) echograms showing the distinct scattering layer due to C. hysoscella and the featureless appearance of A. aequorea. Echograms extend $100 \mathrm{~m}$ vertically and approximately $1.4 \mathrm{~km}$ horizontally; sea bed is visible in the upper panels at about $80 \mathrm{~m}$; display threshold is $-90 \mathrm{~dB}$ (white), and colour scale (left-hand bar) is in $6 \mathrm{~dB}$ steps. Boxes show net sample regions from which pure catches of jellyfish $(650 \mathrm{~kg} \mathrm{C}$. hysoscella, $5340 \mathrm{~kg} \mathrm{~A}$. aequorea) were made. Dense horizontal bands at about $8 \mathrm{~m}$ on both echograms are non-biological; they are due to physical transducer effects 

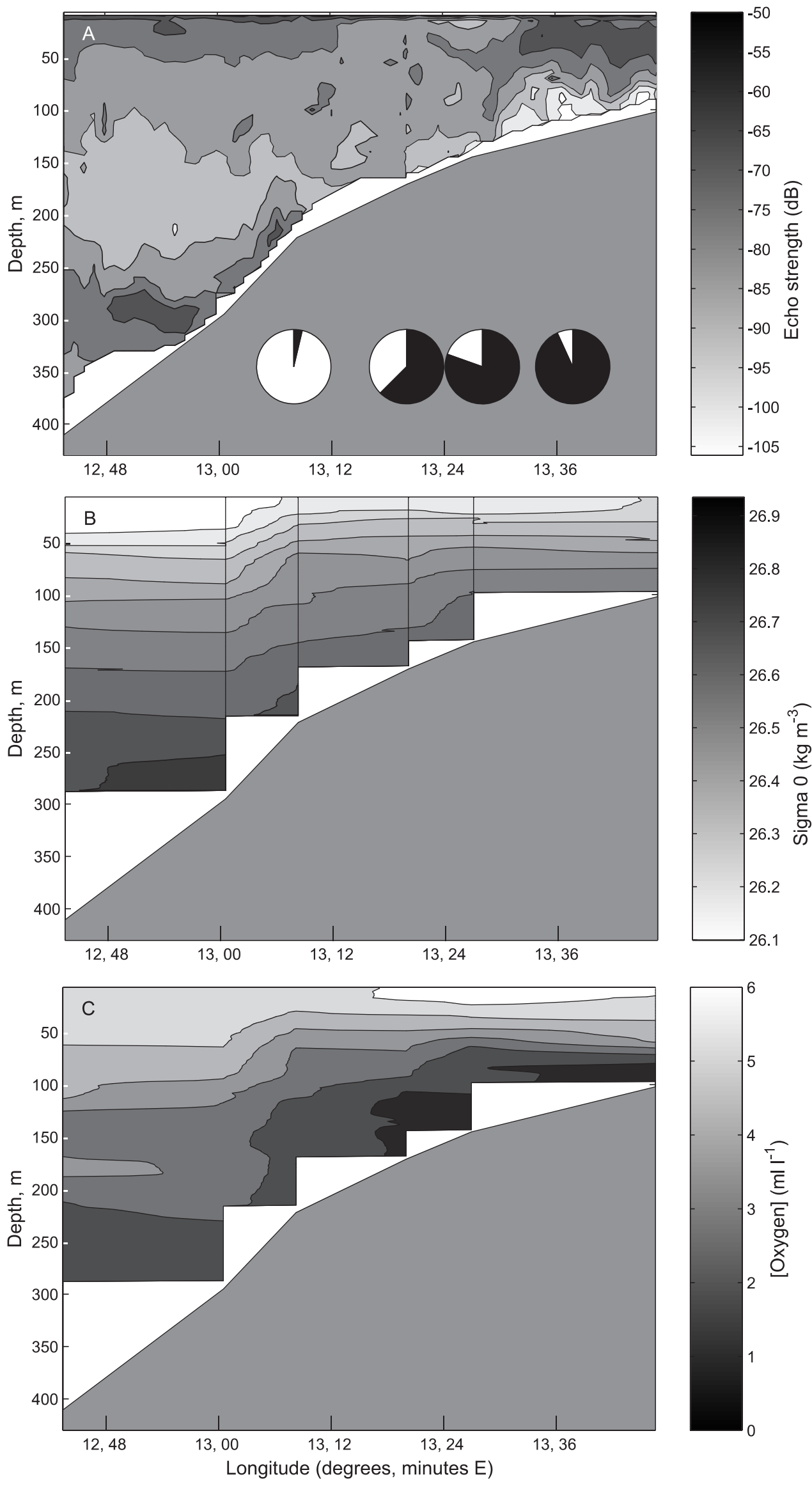

Fig. 4. Off/inshore transect along $22^{\circ} \mathrm{S}$. (A) $38 \mathrm{kHz}$ echogram integrated in $5 \mathrm{~m} \times 1$ nautical mile intervals showing the prominent scattering layer inshore (top right); inset are pie charts showing the relative proportion (by wet mass) of Chrysaora hysoscella (black) and Aequorea aequorea (white) in net catches where jellyfish catch rate $>100 \mathrm{~kg} \mathrm{~min}{ }^{-1}$ (no such catches were made west of $13^{\circ} 7^{\prime}$ E). (B) Seawater density (sigma 0 , vertical lines and $y$-axes mark the positions of CTD casts). (C) Dissolved oxygen concentration (relative) 
observed approaching closer than around $15 \mathrm{~m}$ to the surface in daylight. At night the layer became slightly more diffuse, extending its upper boundary towards the surface, presumably as some of the scatterers within it migrated upwards, while the lower boundary remained distinct. C. hysoscella was caught in the layer, but fishing beneath the lower boundary failed to catch anything. At the coarsest level, evidence that this acoustically detectable layer was composed of $C$. hysoscella comes from the fact that the largest $s_{\mathrm{A}}$ values $\left(250 \mathrm{~m}^{2}\right.$ nautical mile ${ }^{-2}$ at $38 \mathrm{kHz}, 121 \mathrm{~m}^{2}$ nautical mile $^{-2}$ at $120 \mathrm{kHz}$ ) corresponded to the largest trawldetermined numerical density $\left(\approx 3\right.$ per $\left.100 \mathrm{~m}^{3}\right)$ : these data were from a haul near the surface at night that was cut short because very high densities of jellyfish were visible at the surface and we feared that the net would burst. A. aequorea was not caught in association with any particularly obvious echogram feature (Fig. 3), and we are not able to associate a characteristic echo type with this species.

Neither species was caught in large numbers west of $13^{\circ} 7^{\prime} \mathrm{E}$ and, with the exception of obvious pelagic and near-bottom fish marks, the echogram was effectively blank in this region. The density (sigma 0) section in Fig. 4B shows a substantial shelf-break front centered on $13^{\circ} 6^{\prime} \mathrm{E}$, the steeply sloping contours being indicative of the strong northward flowing Benguela current (see Longhurst 1998). It would appear, therefore, that the jellyfish species targeted in this study are predominantly restricted to continental shelf waters.
Comparison of $s_{\mathrm{A}}$ with Chrysaora hysoscella volume density determined from trawl samples produced positive relationships at 18, 38 and $120 \mathrm{kHz}$ (Fig. 5). Slopes of relationships for C. hysoscella at 38 and $120 \mathrm{kHz}$ were significantly different from zero (ANOVA, $\mathrm{p}<0.05$ ). Regression relationships, probabilities and resulting target strengths are given in Table 2. Positive, significant relationships were apparent between $s_{\mathrm{A}}$ and Aequorea aequorea volume density at all 3 frequencies (Table 2). Errors in our estimate of sampled volume due to net distortions away from the idealized circular opening, or from clogging by large catches (see Everson \& Miller 1999, Holliday 1999), may have effected our TS estimates. Net clogging, in particular, may have reduced the effective volume filtered, particularly at high jellyfish densities, leading to an underestimate of animal volume density and consequently to an overestimate of TS per individual.

The larger Chrysaora hysoscella had a substantially greater mean TS per individual ( $>16 \mathrm{~dB})$ at all 3 frequencies than the smaller species, Aequorea aequorea. Once scaled to TS $\mathrm{kg}^{-1}$ (by mean mass per individual), however, the differences between species were less marked, ranging from $3.8 \mathrm{~dB} \mathrm{~kg}^{-1}$ at $18 \mathrm{kHz}$ to $6.9 \mathrm{~dB} \mathrm{~kg}^{-1}$ at $38 \mathrm{kHz}$ (see Table 2). Although there were significant differences between the distributions of $C$. hysoscella umbrella diameters in some net hauls, further analyses attempting to link TS to mean umbrella diameter failed to establish significant relationships at any frequency for this species. For A. aequorea, positive $\mathrm{TS} / \log _{10}$ umbrella
Fig. 5. Chrysaora hysoscella and Aequorea aequorea. Relationships between nautical area scattering coefficients $\left(s_{\mathrm{A}}\right)$ at 18,38 and $120 \mathrm{kHz}$ and volume density of jellyfish. Continuous lines are regressions, which are bounded by their $95 \%$ confidence limits (dashed). Note that $y$-axes are not all at the same scale. n.mi. = nautical mile

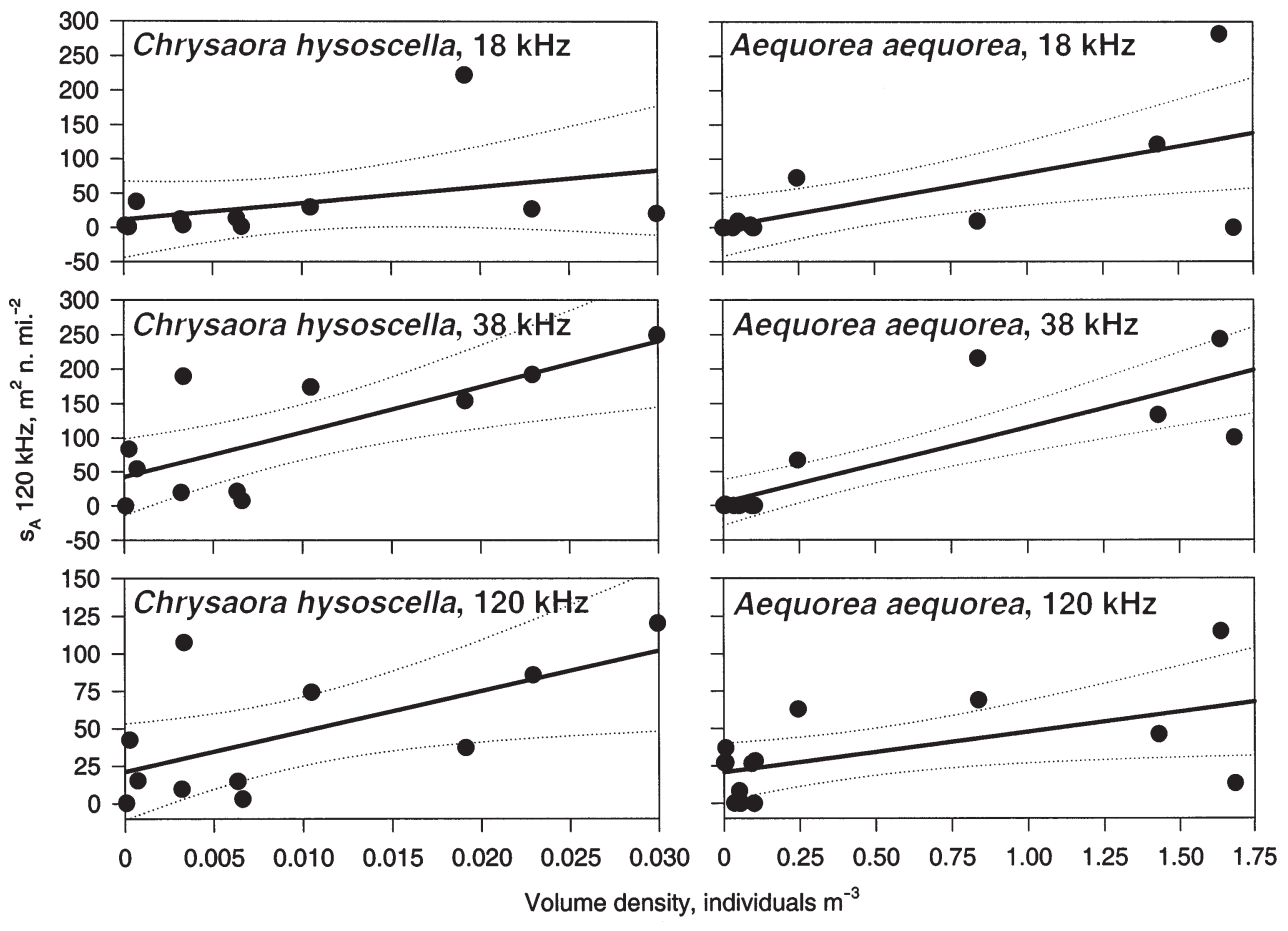


Table 2. Chrysaora hysoscella and Aequorea aequorea. Linear regression relationships and associated $\mathrm{r}^{2}$ and $\mathrm{p}$ (ANOVA, null hypothesis slope $=0$ ) values between nautical area scattering coefficients $\left(s_{\mathrm{A}}, \mathrm{m}^{2}\right.$ nautical mile $\left.{ }^{-2}\right)$ at 18,38 and $120 \mathrm{kHz}$ and volume density $\left(\rho_{\mathrm{v}}, \mathrm{m}^{-3}\right)$. Mean target strengths (TS, dB) per individual and their $95 \%$ confidence intervals (CI) from the regression relationships are shown for both species at each frequency. We are unable to report a lower $95 \%$ CI for TS at $18 \mathrm{kHz}$ for either species because the regression equations suggest $s_{\mathrm{A}}$ to be negative (see Fig. 5). Mean target strengths per kg (based on mean TS and mean wet mass per species) are also given

\begin{tabular}{|lcc|}
\hline & & \\
\cline { 2 - 3 } & C. hysoscella $(1.15 \mathrm{~kg})$ & A. aequorea $(0.06 \mathrm{~kg})$ \\
\hline 18 kHz regression & $S_{\mathrm{A}}=11.8+2385 \rho_{\mathrm{v}}, \mathrm{r}^{2} 0.15, \mathrm{p} 0.25$ & $S_{\mathrm{A}}=0.8+78.8 \rho_{\mathrm{v}}, \mathrm{r}^{2} 0.42, \mathrm{p} 0.01$ \\
$38 \mathrm{kHz}$ regression & $S_{\mathrm{A}}=44.8+6485 \rho_{\mathrm{v}}, \mathrm{r}^{2} 0.54, \mathrm{p} 0.01$ & $S_{\mathrm{A}}=4.7+110.7 \rho_{\mathrm{v}}, \mathrm{r}^{2} 0.70, \mathrm{p} 0.00$ \\
$120 \mathrm{kHz}$ regression & $S_{\mathrm{A}}=22.1+2658 \rho_{\mathrm{v}}, \mathrm{r}^{2} 0.39, \mathrm{p} 0.04$ & $S_{\mathrm{A}}=20.8+27.0 \rho_{\mathrm{v}} \mathrm{r}^{2} 0.30, \mathrm{p} 0.04$ \\
TS $18 \mathrm{kHz}(95 \% \mathrm{CI})$ & $-51.5 \mathrm{~dB}(-48.0 \mathrm{~dB}$ to $-? \mathrm{~dB})$ & $-68.1 \mathrm{~dB}(-65.0 \mathrm{~dB}$ to $-? \mathrm{~dB})$ \\
TS $38 \mathrm{kHz}(95 \% \mathrm{CI})$ & $-46.6 \mathrm{~dB}(-45.1 \mathrm{~dB}$ to $-48.9 \mathrm{~dB})$ & $-66.3 \mathrm{~dB}(-64.5 \mathrm{~dB}$ to $-69.5 \mathrm{~dB})$ \\
TS $120 \mathrm{kHz}(95 \% \mathrm{CI})$ & $-50.1 \mathrm{~dB}(-48.3 \mathrm{~dB}$ to $-53.3 \mathrm{~dB})$ & $-68.5 \mathrm{~dB}(-66.7 \mathrm{~dB}$ to $-71.5 \mathrm{~dB})$ \\
TS kg $18 \mathrm{kHz}$ & $-52.1 \mathrm{~dB}$ & $-55.9 \mathrm{~dB}$ \\
TS kg & $-47.2 \mathrm{~dB}$ & $-54.1 \mathrm{~dB}$ \\
TS kg & $-50.7 \mathrm{~dB}$ & $-56.2 \mathrm{~dB}$ \\
\hline
\end{tabular}

diameter relationships were apparent at all 3 frequencies, and the relationship at $38 \mathrm{kHz}$ was significant (Fig. 6, TS $38 \mathrm{kHz}=-329+298 \log _{10}$ umbrella diameter, $\left.\mathrm{r}^{2}=0.899, \mathrm{p}=0.014\right)$.

\section{DISCUSSION}

Net sample and visual observations made during this survey have shown that the jellyfish Chrysaora hysoscella and Aequorea aequorea occur in very high numerical densities in the northern Benguela ecosystem off Namibia. Our mean catch densities of 1 and 45 individual C. hysoscella and A. aequorea per $100 \mathrm{~m}^{3}$, respectively, in hauls that we have been able to associate directly with acoustic observations (maxima were 3 and 168 per $100 \mathrm{~m}^{3}$ ), when viewed in conjunction with published feeding rates for related species (e.g. Purcell 1989, 1992, Purcell et al. 1994), suggest that by weight of numbers alone, these gelatinous macrozoplankton must now play a considerable role in trophic

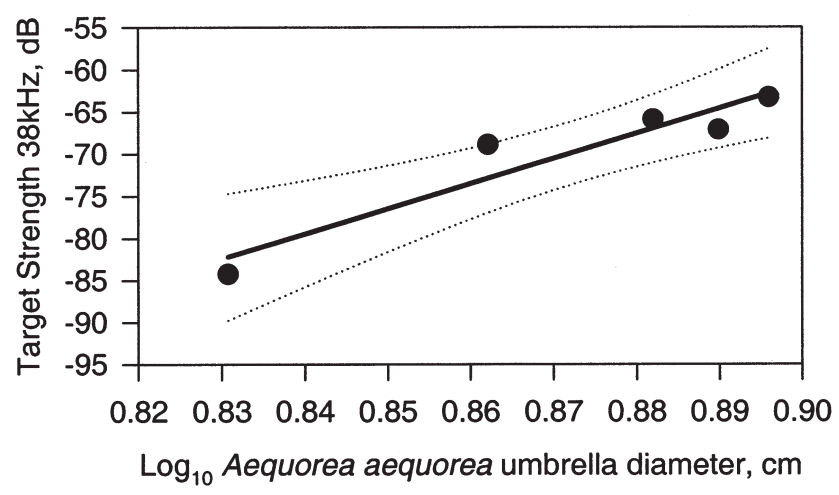

Fig. 6. Aequorea aequorea. Variation of target strength at $38 \mathrm{kHz}$ as a function of umbrella diameter. Continuous line is regression, bounded by $95 \%$ confidence limits (dashed) processes in the northern Benguela. The overall catch maxima during this survey as a whole suggest that the impact is greater still. The possibility that there has been a regime shift in this pelagic ecosystem, with jellyfish proliferating to the detriment of fish (cf. Mills 1995, Purcell et al. 1999), and the further possibility that predation and competition effects may render this paradigm change irreversible, make jellyfish an important group for study.

There are few published TS estimates for jellyfish. Most measurements that have been reported are at or above $120 \mathrm{kHz}$, and were made on species somewhat smaller than Chrysaora hysoscella (e.g. Wiebe et al. 1990, Monger et al. 1998). We are unaware of any previously published $18 \mathrm{kHz}$ TS estimates for jellyfish, and our data must therefore be viewed in isolation. The only $38 \mathrm{kHz}$ data of which we are aware are observations by O. Nakken (cited in Mutlu 1996) on Aurelia autrans, where TS was reported to range from $-54 \mathrm{~dB}$ for an individual $8 \mathrm{~cm}$ in diameter to $-51.7 \mathrm{~dB}$ for a 16 $\mathrm{cm}$ specimen. These values are much higher (by about $12 \mathrm{~dB}$ ) than our observations on similarly sized Aequorea aequorea (mean central umbrella diameter $7.5 \mathrm{~cm}$ ), but only about $3 \mathrm{~dB}$ below the lower $95 \%$ confidence interval $(-48.9 \mathrm{~dB})$ that we determined for $C$. hysoscella TS at $38 \mathrm{kHz}$ (see Table 2). Nakken is also reported to have made measurements at $120 \mathrm{kHz}$ (see Mutlu 1996), finding TS between $-54.2 \mathrm{~dB}$ (8 cm diameter) and $-50.1 \mathrm{~dB}(16 \mathrm{~cm})$. Nakken's value for the 16 $\mathrm{cm}$ individual is equivalent to our mean TS for C. hysoscella at $120 \mathrm{kHz}$, and Fig. 2 shows that the range of $C$. hysoscella diameters we encountered includes $16 \mathrm{~cm}$. Nakken's $8 \mathrm{~cm} 120 \mathrm{kHz}$ TS is however substantially greater than our estimate at this frequency for $A$. aequorea. Chrysaora and Aurelia are both members of the order Semaeostomeae (scyphomedusae), whereas Aequorea is a member of the order Leptomedusae 
(hydromedusae). The large differences in TS between our observations on Aequorea and Nakken's on Aurelia could be due in part to differences in their body composition that may be reflected in their more distant taxonomic classification: female Aurelia spp. carry clumps of developing larvae, and the gonads can be very dense; scyphomedusae are generally more robust than hydromedusae; the umbrella of scyphomedusae is thicker and firmer and they have long, dense oral arms; the mesoglea of scyphomedusae is composed of living tissue and, finally, hydromedusae have a simple gastric sack, whereas scyphomedusae have convoluted gastric pouches. The carbon content of the 2 groups may also differ (e.g. Larson 1987). Monger et al. (1998) have suggested that the large differences in TS between the gelatinous zooplankton Aequorea and Pleurobrachia (a ctenophore) were due to differences in sound-scattering properies. Density and soundspeed contrasts, among other things (see Stanton et al. 1996), affect the degree to which objects scatter sound. We were only able to measure density for C. hysoscella and $A$. aequorea in the present study: these measurements did suggest differences between species (density was $0.996 \mathrm{~kg} \mathrm{l}^{-1}$ for C. hysoscella and $1.014 \mathrm{~kg} \mathrm{l}^{-1}$ for $A$. aequorea) but, without replication, are inconclusive.

Mutlu (1996) made measurements of backscatter at 120 and $200 \mathrm{kHz}$ from caged Aurelia aurita (umbrella diameter 9.5 to $15.5 \mathrm{~cm}$ ). Extrapolation from his $120 \mathrm{kHz}$ TS/umbrella diameter relationship gives a TS of $-53.6 \mathrm{~dB}$ for an individual $27 \mathrm{~cm}$ in diameter (the mean for Chrysaora hysoscella in this study), which is only just below our lower $95 \%$ confidence interval for $C$. hysoscella TS (-53.3 dB, see Table 2). Extrapolation in the opposite direction to diameter $7.5 \mathrm{~cm}$ gives a TS at $120 \mathrm{kHz}$ of $-61.7 \mathrm{~dB}$, which is somewhat higher that our estimate of $-68.5 \mathrm{~dB}$ for Aequorea aequorea. Again then, there is closer agreement with our and previously published TS estimates within the order Semaeostomae than without.

Monger et al. (1998) made measurements of Aequorea victoria (diameters between 2.6 and $5.8 \mathrm{~cm}$ ) at 200, 420 and $1000 \mathrm{kHz}$. They used reduced target strength (RTS),

$$
\mathrm{RTS}=10 \log _{10} \frac{<\sigma_{\mathrm{bs}}>}{\pi a^{2}}
$$

(where $a$ is the individual's radius) to compare their TS estimates with those made by Mutlu (1996) for larger individuals at lower frequencies. Monger et al. (1998) reported an RTS, averaged over all frequencies and sizes, of $-43.3 \mathrm{~dB}$, and stated that their observations were 'in very good agreement' with those of Mutlu (1996) (RTS $=-40.7 \mathrm{~dB}$ calculated from their Table 1). Averaged in the same way, our RTS value for $A$. aequorea (assuming a diameter of $7.5 \mathrm{~cm}$ ) is $-44.1 \mathrm{~dB}$, and is $-37.0 \mathrm{~dB}$ for C. hysoscella (diameter $27 \mathrm{~cm}$ ). We compare published TS values from all species, sizes and frequencies with our own observations by plotting RTS against $k a$ ( $k$ is wavenumber $=2 \pi / \lambda$, and $a$ is jellyfish radius) (Fig. 7). Our RTS estimates fall within the (albeit large) bounds of previous estimates. The strong dependence of RTS upon ka when ka is low (Rayleigh scattering), evident from our $A$. aequorea data in Fig. 7, is also noteworthy, since it is in general agreement with both sound-scattering theory (see Medwin \& Clay 1998) and specific predictions made by models of sound scattering by A. victoria (Monger et al. 1998; see their Fig. 6). The gradient of the regression equation of TS against $\log _{10}$ umbrella diameter upon which this is based (see present Fig. 6) is far steeper than the slope usually expected for fish (see MacLennan \& Simmonds 1992). This is probably due in part to the fact that echo-sounder frequencies used for fishery acoustic surveys are usually chosen to be high enough to provoke geometric rather than Rayleigh scattering from the target species.

It is possible that the TS values we have obtained here by the comparison method are greater than the true values. We are unable to discount the possibility that organisms in addition to the jellyfish that were retained in the trawl contributed to detected echo intensities. We were unable to sample zooplankton, for example, in the pelagic trawl, and the smallest organisms we retained were myctophid fish $(\sim 5 \mathrm{~cm})$. The productive Benguela boundary current ecosystem

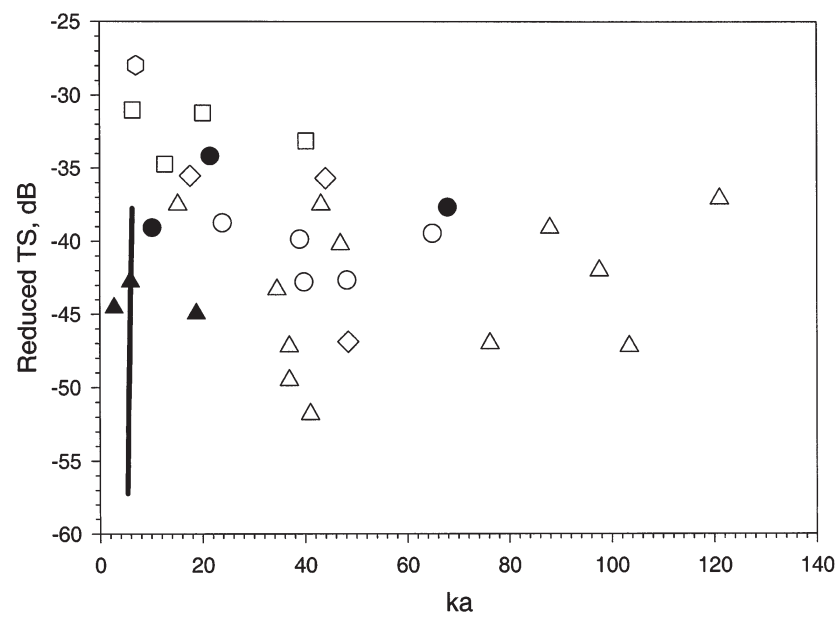

Fig. 7. Summary of reduced target strength (TS) against ka for various jellyfish species ( $k$ is wavenumber $=2 \pi / \lambda, a$ is jelly-

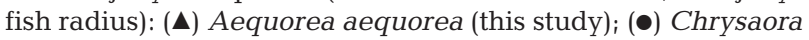
hysoscella (this study); line $=A$. aequorea $38 \mathrm{kHz}$ regression (this study, see Fig. 6); $(\triangle)$ Aequorea victoria (Monger et al. 1998); (O) Aurelia aurita (Mutlu 1996); () Aurelia autrans (O. Nakken, cited in Monger et al. 1998); $(\diamond)$ Aequorea victoria (Wiebe et al. 1990); (○) Aurelia aurita (Saito et al. 1990, cited in Toyokawa et al. 1997) 
(Baird et al. 1991) supports rich zooplankton communities (e.g. Barange \& Stuart 1991, Gibbons \& Hutchings 1996), and even small zooplankton can produce intense echoes (see Stanton et al. 1996). The scattering layer we observed may have been due to small zooplankton, and the jellyfish may have been aggregating in the layer because the food supply was elevated there. However, for reasons outlined earlier, we believe that the scattering layer was predominantly due to jellyfish. TS estimates reported by Monger et al. (1998) would not have been subject to this source of error, since their measurements were made in an enclosure containing seawater filtered through $53 \mu \mathrm{m}$ netting. In addition to possible contamination by free-swimming zooplankton, Chrysaora hysoscella was also parasitized by hyperiid amphipods (including Hyperia galba, mean infestation level 1.4 parasites per jellyfish) which would also have contributed to $\sigma_{\text {bs }}$ (cf. Trevorrow \& Tanaka 1997). We also observed air bubbles inside the gonads and gastric pouch of C. hysoscella which were almost certainly introduced during trawling. If these were natural occurrences, however, then these too would have contributed to TS.

Although our TS values may potentially be higher than laboratory-determined values, the fact that our data were collected in the field makes them valuable for consideration of the effect that jellyfish could have on acoustic estimates of fish biomass, because during fish surveys it will be whole water-column values rather that idealized laboratory values that are obtained. Field observations will also include echoes from animals in varying orientations: tank measurements tend to be made on tethered animals held in 1 direction only, but orientation may have considerable effect on TS. Mutlu (1996) has also shown that jellyfish TS changes as umbrella diameter oscillates during swimming. Field observations will be of a 'mean' swimming dilation, which may be different to that adopted by anaesthetized, tank-held individuals. In situ TS estimates using multifrequency techniques (Demer et al. 1999) that avoid shortcomings of more basic single-target detection algorithms (see Soule et al. 1995) could provide valuable additional data on the acoustic properties of jellyfish, and offer an obvious avenue for future research.

The high numerical densities and apparently not insubstantial TS that we have observed for Chrysaora hysoscella and Aequorea aequorea raises the possibility that echoes from these jellyfish may bias acoustic estimates of fish biomass. Indeed, Purcell et al. (2000) have reported that in Prince William Sound nets targeted at acoustic features thought to be fish schools sometimes resulted in large catches of $A$. aequorea. Acoustic surveys are conducted in the Benguela ecosystem to estimate stock sizes of pilchard, horse mack- erel and anchovies (e.g. Barange et al. 1996). An important stage in the interpretation of acoustic survey data is ensuring that only echoes from the species under investigation are included in estimates of biomass. In the Southern Ocean, for example, acoustic survey techniques are used to estimate sizes of Antarctic krill Euphausia superba stocks. Madureira et al. (1993) developed a 2-frequency acoustic classification that allowed echoes from krill to be distinguished from squid/fish and zooplankton. The technique works because these different groups of animals have different relative TS at 38 and $120 \mathrm{kHz}$ and, as a consequence, calculation of $\Delta \mathrm{MVBS}_{120 \mathrm{kHz}-38 \mathrm{kHz}}$ the difference in mean volume backscattering strength $\left(S_{\mathrm{v}}, \mathrm{dB}\right.$ re $1 \mathrm{~m}^{-1}$ ) at 120 and $38 \mathrm{kHz}$, allows them to be separated: targets where $2 \mathrm{~dB} \leq \Delta \mathrm{MVBS}_{120 \mathrm{kHz}-38 \mathrm{kHz}} \leq 12 \mathrm{~dB}$ are classified as krill. This technique is now used routinely for krill biomass estimation (e.g. Brierley et al. 1997, 1999), and has been extended using an additional frequency $(200 \mathrm{kHz})$ to identify additional zooplankton taxa (Brierley et al. 1998). A technique of this kind could have utility in the Benguela system. Nakken \& Olsen (1977) have reported TS estimates for fishes at 120 and $38 \mathrm{kHz}$, and their data suggest a mean $\triangle \mathrm{MVBS}_{120 \mathrm{kHz}-38 \mathrm{kHz}}$ of $3.1 \mathrm{~dB}$ for horse mackerel (33 cm long). The $\triangle \mathrm{MVBS}_{120 \mathrm{kHz}-38 \mathrm{kHz}}$ for C. hysoscella and $A$. aequorea are $-3.3 \mathrm{~dB}$ (range from $95 \% \mathrm{CI}=0.6$ to $-8.2 \mathrm{~dB}$ ) and $-2.2 \mathrm{~dB}$ (range $=2.8$ to $-7.0 \mathrm{~dB}$ ) respectively: the difference between jellyfish and mackerel offers a potential discriminant function. Although there have been several recent studies on the TS of anchovy and pilchard at $38 \mathrm{kHz}$, we have been unable to find data at $120 \mathrm{kHz}$. Barange et al. (1996) have suggested that the closest comparison would be with herring, and Edwards et al. (1984) have reported TS values for mixed herring/sprat aggregations of $-49.0 \mathrm{~dB}$ at $38 \mathrm{kHz}$ and $-51.6 \mathrm{~dB}$ at $120 \mathrm{kHz}$ : this yields a $\Delta \mathrm{MVBS}_{120} \mathrm{kHz}-38 \mathrm{kHz}$ of $-2.6 \mathrm{~dB}$, which is similar to jellyfish. This simple technique is clearly species- (and probably size)-specific, and does not offer a universal solution for jellyfish/fish discrimination. In the case of $A$. aequorea, where the $s_{\mathrm{A}}$ density relationship was significant, additional discriminatory power could perhaps be brought to bear using $18 \mathrm{kHz}$ data as well (cf. Brierley et al. 1998), but we have been unable to find published TS estimates for these fish species at $18 \mathrm{kHz}$.

It has not been possible for us to distinguish between Chrysaora hysoscella and Aequorea aequorea on the basis of relative echo intensities at 120 and $38 \mathrm{kHz}$ alone. Previous studies attempting to use acoustic observations to identify species have found that inclusion of additional information, for example on location in the water column, often improves powers of discrimination (Haralabous \& Georgakarakos 1996, Brierley et al. 1998). Consideration of prevailing oceanographic 
conditions might also help. Inspection of the density and relative oxygen concentration sections in Fig. 4 in conjunction with the echogram and species-catch distribution reveals that $C$. hysoscella was caught inshore in association with the elevated oxygen levels. The scattering layer is very obvious here. The transition from dominance in catch of $C$. hysoscella to $A$. aequorea occurs around $13^{\circ} 24^{\prime} \mathrm{E}$, and is coincident with a discontinuity in both oxygen concentration and density. This discontinuity is not as pronounced as the shelf-break front, but nevertheless reveals that the shelf waters are not homogenous. The scattering layer disperses in the vicinity of the oceanographic discontinuity and provides further evidence that the 2 species of jellyfish are differentially distributed. One explanation for this difference might be that C. hysoscella, with its greater body size, has a requirement for welloxygenated waters (but see Breitburg et al. 1999), and is restricted from regions further offshore influenced by the encroaching oxygen minimum that is a feature of the Benguelan upwelling (see Longhurst 1998).

Combinations of acoustic, oceanographic and net sampling data will be needed to fully understand factors influencing the distribution and abundance of Chrysaora hysoscella and Aequorea aequorea in the northern Benguela current ecosystem. Such combinations will however be of use in Namibian waters, and may serve to aid commercial fishing activities, reducing incidences of net burst, and inform diamond extractors when it is likely that jellyfish may hamper their activities, in addition to revealing more of the ecological dynamics of a group of organisms that are becoming increasingly important in marine ecosystems worldwide.

Acknowledgements. We thank the Benefit Committee for allocating ship time to this study, NORAD for providing the FRV 'Dr Fridtjof Nansen' and D. Boyer of the National Information and Marine Research Centre (NIMRC), Swakopmund, for assistance with the planning of this project. We are grateful to the captain and crew of the FRV 'Dr Fridtjof Nansen' for their tireless efforts in catching jellyfish and repairing nets, R. Skeide for multinet operation, and T. Mørk for acoustic and computing support. M. Evenson, A. Heita and G. Oechslin (NIMRC) provided invaluable assistance at sea. We thank Dr M. Barrange (Marine and Coastal Management, [MCM] South Africa) and I. Higginbottom (SonarData Pty Ltd, Australia) for enabling us to use Echoview, and M. Soule (MCM) for echo-sounder calibration data. Dr M. Brandon and E. Hawker British Antarctic Survey (BAS) provided advice on analysis of oceanographic data. A.S.B. thanks the Royal Society (London) for supporting his travel, MCM for office facilities in Cape Town, and Professor A. Clarke and the Director, BAS, for their permission to participate in this study. Thanks additionally are owed to the France-South Africa Science and Technology Exchange Agreement, the Singer Polignac Foundation and to de Beers Marine Pty Ltd for supporting E.B. and C.A.J.S.

\section{LITERATURE CITED}

Baird D, McGlade JM, Ulanowicz RE (1991) The comparative ecology of 6 marine ecosystems. Phil Trans R Soc Lond Ser B Biol Sci 333:15-29

Barange M, Stuart V (1991) Distribution patterns, abundance and population-dynamics of the euphausiids Nyctiphanes capensis and Euphausia hanseni in the northern Benguela upwelling system. Mar Biol 109:93-101

Barange M, Hampton I, Soule M (1996) Empirical determination of in situ target strengths of three loosely aggregated pelagic fish species. ICES J Mar Sci 53:225- 232

Breitburg DL, Rose KA, Cowan JH (1999) Linking water quality to larval survival: predation mortality of fish larvae in an oxygen-stratified water column. Mar Ecol Prog Ser 178:39-54

Brierley AS, Watkins JL, Murray AWA (1997) Interannual variability in krill abundance at South Georgia. Mar Ecol Prog Ser 150:87-98

Brierley AS, Ward P, Watkins JL, Goss C (1998) Acoustic discrimination of Southern Ocean zooplankton. Deep-Sea Res II 45:1155-1173

Brierley AS, Watkins JL, Goss C, Wilkinson MT, Everson I (1999) Acoustic estimates of krill density at South Georgia, 1981 to 1998. CCAMLR Sci 6:47-57

Demer DA, Soule MA, Hewitt RP (1999) A multiple-frequency method for potentially improving the accuracy and precision of in situ target strength measurements. J Acoust Soc Am 105:2359-2376

Edwards JL, Armstrong F, Magurran AE, Pitcher TJ (1984) Herring, mackerel and sprat target strength experiments with behavioural observations. Int Counc Explor Sea Comm Meet 1984/B:34:1-21 (mimeo)

Everson I, Miller D (1999) Biological sampling. In: Ona E (ed) Methodology for target strength measurements (with special reference to in situ techniques for fish and micronekton). Int Counc Explor Sea Coop Res Rep 235:44-47

FAO (1995) World fishery production 1950-1993. Supplement to the FAO yearbook of fishery statistics 1993, Vol 76. Catches and landings. FAO, Rome

Fearon JJ, Boyd AJ, Schülen FH (1991) Views on the biomass and distribution of Chrysaora hysoscella (Linné, 1766) and Aequorea aequorea (Forskål, 1775) off Namibia, 19821989. Sci Mar 56:75-85

Gal G, Rudstam LG, Greene CH (1999) Acoustic characterization of Mysis relicta. Limnol Oceanogr 44:371-381

Gibbons MJ, Hutchings L (1996) Zooplankton diversity and community structure around southern Africa, with special attention to the Benguela upwelling system. S Afr J Sci 92:63-76

Gibbons MJ, Stuart V, Verheye HM (1992) Trophic ecology of carnivorous zooplankton in the Benguela. S Afr J Mar Sci 12:421-437

Haralabous J, Georgakarakos S (1996) Artificial neural networks as a tool for species identification of fish schools. ICES J Mar Sci 53:73-180

Hart TJ, Currie RI (1960) The Benguela Current. Discov Rep 31:123-298

Holliday DV (1999) Measuring target strengths for zooplankton and micronekton. In: Ona E (ed) Methodology for target strength measurements (with special reference to in situ techniques for fish and micronekton). Int Counc Explor Sea Coop Res Rep 235:50-58

Larson RJ (1987) Respiration and carbon turnover rates of medusae from the NE Pacific. Comp Biochem Physiol A87: 93-100 
Longhurst A (1998) Ecological geography of the sea. Academic Press, London

MacLennan DN, Fernandes PG (1999) Recommended guidelines for use of terms and symbols in fisheries acoustic publications. Report of the Working Group on Fisheries Acoustics Science and Technology 1999. Int Counc Explor Sea Comm Meet 1999/B:2:1-29 (mimeo)

MacLennan DN, Simmonds EJ (1992) Fisheries acoustics. Chapman \& Hall, London

Madureira LSP, Everson I, Murphy EJ (1993) Interpretation of acoustic data at two frequencies to discriminate between Antarctic krill (Euphausia superba Dana) and other scatterers. J Plankton Res 15:787-802

Medwin H, Clay CS (1998) Fundamentals of acoustical oceanography. Academic Press, Boston

Mills CE (1995) Medusae, siphonophores and ctenophores as planktivorous predators in changing global ecosystems. ICES J Mar Sci 52:575-581

Misund OA, Beltestad AK (1996) Target-strength estimates of schooling herring and mackerel using the comparison method. ICES J Mar Sci 53:281-284

Monger BC, Chinniah-Chandy S, Meir E, Billings S, Greene $\mathrm{CH}$, Wiebe PH (1998) Sound scattering by the gelatinous zooplankters Aequorea victoria and Pleurobrachia bachei. Deep-Sea Res II 45:1255-1271

Mutlu E (1996) Target strength of the common jellyfish (Aurelia aurita): a preliminary experimental study with a dualbeam acoustic system. ICES J Mar Sci 53:309-311

Nakken O, Olsen K (1977) Target strength measurements of fish. Rapp P-V Réun Cons Int Explor Mer 170:52-69

Ona E (ed) (1999) Methodology for target strength measurements (with special reference to in situ techniques for fish and micronekton). Int Counc Explor Sea Coop Res Rep 235:59

Pagès F (1991) Ecología y sistemática de los Cnidarios planctónicos de la corriente de Benguela (Atlántico Sudoriental). PhD thesis, University of Barcelona

Purcell JE (1989) Predation on fish larvae and eggs by the hydromedusa Aequorea victoria at a herring spawning ground in British Colombia. Can J Fish Aquat Sci 46: $1415-1427$

Purcell JE (1992) Effects of predation by the scyphomedusan Chrysaora quinquecirrha on zooplankton populations in Chesapeake Bay, USA. Mar Ecol Prog Ser 87:65-76

Purcell JE, Siferd TD, Marliave JB (1987) Vulnerability of herring larvae (Clupea harengus pallasi) to capture by jellyfish Aequorea victoria. Mar Biol 94:157-162

Purcell JE, Nemazie DA, Dorsey SE, Houde ED, Gamble JC (1994) Predation mortality of bay anchovy Anchoa mitchilli eggs and larvae due to scyphomedusae and ctenophores in Chesapeake Bay. Mar Ecol Prog Ser 114:47-58

Purcell JE, Malej A, Benovic A (1999) Potential links of jellyfish to eutrophication and fisheries. Coast Estuar Stud 55: 241-236

Purcell JE, Brown ED, Stokesbury KDE, Haldorsen LH, Shirley TC (2000) Aggregations of the jellyfish Aurelia labiata: abundance, distribution, association with age-0 walleye pollock, and behaviors promoting aggregation in Prince William Sound, Alaska, USA. Mar Ecol Prog Ser 195:145-158

Editorial responsibility: Otto Kinne (Editor), Oldendorf/Luhe, Germany
Saito KN, Hamada N, Tepparoonrat Y, Sasakura T (1990) Report on the target strength of Aurelia aurita. Rep Annu Meet Natl Res Inst Fish Tech 111-114 (in Japanese)

Shannon LV, Crawford RJM, Pollock DE, Hutchings L, Boyd AJ, Taunton-Clark J, Badenhorst A, Melville-Smith R, Augustyn CJ, Cochrane KL, Hampton I, Nelson G, Japp DW, Tarr RJQ (1992) The 1980s - a decade of change in the Benguela ecosystem. S Afr J Mar Sci 12:271-296

Simmonds EJ, Armstrong F, Copland PJ (1996) Species identification using wideband backscatter with neural network and discriminant analysis. ICES J Mar Sci 53:189-195

Skeide R, Engås A, West CW (1997) Multisampler-a new tool for use in sampling trawls. In: Shleinik V, Zaferman M (eds) Seventh IMR-PINRO Symposium: Gear selection and sampling gears. Murmansk 23-24 June 1997. PINRO Press, Murmansk, p 65-76

Soule MA, Barange M, Hampton I (1995) Evidence of bias in estimates of target strength obtained with split-beam echo-sounder. ICES J Mar Sci 52:139-144

Sparks CEJ, Buecher E, Brierley AS, Axelsen BE, Boyer H, Gibbons MJ (2000) Observations on the distribution and relative abundance of the scyphomedusan Chrysaora hysoscella (Linné, 1766) and the hydrozoan Aequorea aequorea (Forskål, 1755) in the northern Benguela ecosystem. Hydrobiologia (in press)

Stander GH, de Decker AHB (1969) Some physical and biological aspects of an oceanographic anomaly off South West Africa in 1963. Invest Rep Div Sea Fish Repub S Afr 81:1-46

Stanton TK, Chu DZ, Wiebe PH (1996) Acoustic scattering characteristics of several zooplankton groups. ICES J Mar Sci 53:289-295

Suchman CL, Sullivan BK (1998) Vulnerability of the copepod Acartia tonsa to predation by the scyphomedusa Chrysaora quinquecirrha: effect of prey size and behaviour. Mar Biol 132:237-245

Toyokawa M, Inagaki T, Terazaki M (1997) Distribution of Aurelia aurita (Linnaeus, 1758) in Tokyo Bay; observations with echosounder and plankton net. In: den Hartog JC (ed) Proceedings of the Sixth International Symposium on Coelenterate Biology 1995. Natuurhistorisch Musem, Leiden, p 483-490

Travis J (1993) Invader threatens Black and Azov Seas. Science 262:1366-1367

Trevorrow MV, Tanaka Y (1997) Acoustic and in situ measurements of freshwater amphipods (Jesogammarus annandalei) in Lake Biwa, Japan. Limnol Oceanogr 42: 121-132

Valdemarsen JW, Misund OA (1994) Trawl design and techniques used by Norwegian research vessels to sample fish in the pelagic zone. In: Hylen A (ed) Sixth IMR-PINRO Symposium: Precision and relevance of pre-recruit studies for fishery management related to fish in the Barents Sea and adjacent waters. Institute of Marine Research, Bergen 14-17 June 1994, p 135-144

Wiebe PH, Greene CH, Stanton TK, Burczynski J (1990) Sound scattering by live zooplankton and micronektonempirical studies with a dual-beam acoustical system. J Acoust Soc Am 88:2346-2360

Submitted: March 16, 2000; Accepted: August 8, 2000

Proofs received from author(s): November 20, 2000 